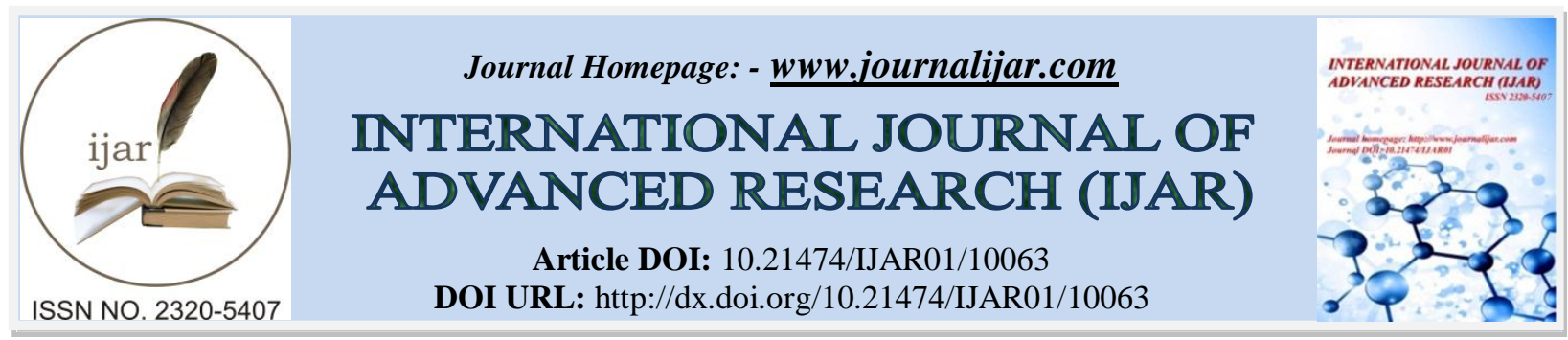

RESEARCH ARTICLE

\title{
CONSERVATION OF ELECTRICAL ENERGY ON THE NATIONAL STREET LIGHTING BASED ON ENVIRONMENT.
}

\author{
Janter Napitupulu ${ }^{1}$, Nasruddin M.N ${ }^{2}$, Immanuel Munthe ${ }^{3}$ and Setia Megawati ${ }^{4}$ \\ 1. Faculty of Engineering, University of Darma Agung, Indonesia. \\ 2. Faculty of Mathematics and Natural Sciences, University of Sumatera Utara, Indonesia. \\ 3. Immanuel Industrial Engineering Academy, Indonesia. \\ 4. Universitas of Sari Mutiara Indonesia, Indonesia.
}

\section{Manuscript Info}

Manuscript History

Received: 12 September 2019

Final Accepted: 14 October 2019

Published: November 2019

Key words:-

Electric power, Energy conservation, Solar cell, Sunlight.

\begin{abstract}
Electric power is an essensial energy used all the time for human life. Even, the used of electric power could be as a parameter for showing the prosperity of a nation. Recently, lack of electric power causes the transfer of conventional energy consumption to renewable energy. North Sumatera Province lies on the equator. Therefore solar cell becomes one of the option used to generate electricity by converting sunlight into electricity. Solar cell can be used as a source of energy for street lighting at night. The length of national roads is always increasing every year built by government. In 2019, the overall length of national roads becomes $2632.22 \mathrm{Kms}$. The increase of the length of this national road causes the need for increased electrical power. By using solar cells as a source of energy replacing conventional energy sources, so energy conservation can be generated. All the lamps SON, 400 Watts, 220 Volts are changed to LED, 100 Watt, 24 Volts. By replacing SON lamp into LED lamps which the solar cells as an energy source will provide a carbon dioxide emission reduction. Energy conservation and Carbon emission reduction in a region will have an impact on air condition.

Copy Right, IJAR, 2019,. All rights reserved.
\end{abstract}

\section{Introduction:-}

The use of renewable energy is one of government policy to preserve nature. Shortage of electrical energy during peak loads causes attempts to used other energy sources to meet the needs of street lighting [1].

In fact a small disturbance in power system can affect the distribution of electrical power to the electrical load. Generator is a source of electrical energy that has the capacity to generate electrical energy to electrical load. If the electrical load is greater than the power generated will turn the power outage to the comsumer. As a solution is to apply energy conservation.

The goal with energy conservation techniques is reduce demand, protect and replenish supplies, develop and use alternative energy sources, and to clean up the damage from the prior energy process [2]. The alternative energy sources in this case is solar cell [3]. There are two causes of solar cell used. The first is finite supply of fuels that is used for generation of electrical energy and the second is the environmental hazard of disposing of the waste product

Corresponding Author:-Janter Napitupulu.

Address:-Faculty of Engineering, University of Darma Agung, Indonesia. 
from the conversion process. Management of electrical energy will result in lower cost[4], Conservation canbe achieve by auditing and optimization[5].

The environmental hazard can be measured from the value of carbon dioxide $\left(\mathrm{CO}_{2}\right)$ emission and determined by $\mathrm{CO}_{2}$ factor as $1.14 \mathrm{KgCO}_{2} / \mathrm{KWh}$.

\section{Research Method:-}

Electrical Power:-

The Electrical Energy used by the Lamp Electric power is calculated as follows:

$\mathrm{P}=\mathrm{Vx} \mathrm{I} \times \operatorname{Cos} \varphi$

Where :

1. $\mathrm{P}$ is electrical power (Watt)

2. V is electrical voltage (Volt)

3. I is electric current (Amp.)

$\operatorname{Cos} \varphi$ is power factor

Energy is the electrical power used at certain time interval.

$\mathrm{W}=\mathrm{Px} \mathrm{t}$

Where,

$\mathrm{W}$ is energi (Joule)

$\mathrm{t}$ is time (Second)

$\mathrm{W}=(\mathrm{P} / 1000) \times(\mathrm{t} / 3600) \mathrm{KWh}$

$\mathrm{W}=2.78 \times 10^{-7} \mathrm{P} \times \mathrm{t} \mathrm{KWh}$

Then, 1 Joule $=2.78 \times 10^{-7} \mathrm{KWh}$ or vice versa, $1 \mathrm{KWh}=3.6 \times 10^{6}$ Joule.

State Electricity Company sells electrical power to comsumers in the form of complex power, then the calculation of the energy absorbed by the electrical load is

$\mathrm{W}=\mathrm{S} \times \mathrm{t}$

$\mathrm{W}=(\mathrm{P} / \mathrm{pf}) \mathrm{xt}$

or,

$\mathrm{W}=\mathrm{KWh} / \mathrm{pf}$

\section{Solar Cell Power:-}

Electric power generated by solar cells is the result of the multiplication of output voltage and current:

$\mathrm{P}=\mathrm{Vx} \mathrm{I}$

Where,

$\mathrm{P}$ is output power $(\mathrm{KW})$

$\mathrm{I}$ is current (ampere)

$\mathrm{Pav}=\left\{\mathrm{P}_{1}+\mathrm{P}_{2}+\mathrm{P}_{3}+\ldots .+\mathrm{P}_{\mathrm{n}}\right\} / \mathrm{n}$

Where,

$\mathrm{P}_{\mathrm{av}}$ is average power $(\mathrm{KW})$

$\mathrm{P}_{1}+\mathrm{P}_{2}+\mathrm{P}_{3}+\ldots .+\mathrm{P}_{\mathrm{n}}$ adalah power at the point of each solar cell panel

A solar cell in generating electrical energy (sunlight energy into photons) will constantly produce energy at 2 Ampere with a voltage of 0.5 Volts or 0.6 Volts maximum voltage. 
Theoretically, the potential of solar resources is the average solar energy on the earth's surface expressed in Kilowatthour (KWh) of the heat energy incident on square meter in the horizontal plane [6]. In Indonesia which is a tropical region has the potensial of solar energy where the average daily insolation is $4.5-4.8 \mathrm{KWh} / \mathrm{m}^{2} / \mathrm{day}$.

Solar cells convert solar radiation in $\mathrm{KWh} / \mathrm{m}^{2} /$ day units into electrical power based on,

$\mathrm{P}=\operatorname{Ir} \mathrm{x} \mathrm{A}$

Where,

Ir is the intensity of solar radiation

A is wide of solar cells $\left(\mathrm{m}^{2}\right)$

The light of the sun that falls on the surface of the earth at bright day is capable of providing power of 1000 Watt $/ \mathrm{m}^{2}$ which will produce a current of about $30 \mathrm{~mA} / \mathrm{cm}^{2}$.

If a semiconductor device of $1 \mathrm{~m}^{2}$ has a $10 \%$ eficiency, this solar cell module is capable of providing 100 Watt of electrical power.

To determine the capacity of the solar cell module, obtained by taking into account the electrical power generated, depending on the level of sunlight irradiation. The greater the degree of solar irradiation the greater the electrical power that the solar cell module can generate. Fig 1, shows the shape of a model of solar irradiation value[7].

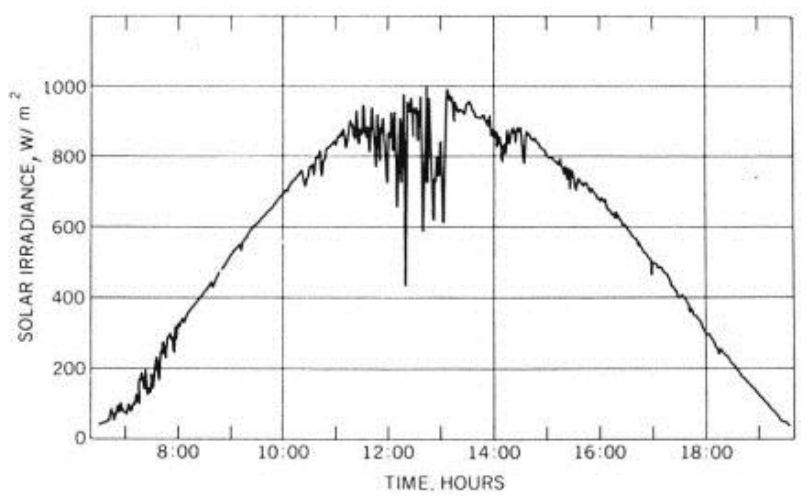

Fig 1:-Model Graph of Solar Irradiation Value

From the graph, the highest irradiation value is betwen the hours of $11.00-13.00$ with an irradiation value of 1000 $\mathrm{W} / \mathrm{m}^{2}$. This value is fluctuating, depending on weather and climate.

Conservation Approach Model PJun-ss:- $_{\text {PJ }}$

$\mathrm{P}_{\mathrm{PIUN}-S \mathrm{~S}}$ approach model is a model approach with the utilization of solar cells as a source of energy for LED light in national street lighting. Energy conservation can be obtained as follow:

$\mathrm{P}_{\text {PJUN-SS }}=\mathrm{P}_{\text {PJUN-LED }}$

$\mathrm{P}_{\text {Konsv-SS }}=\left(\mathrm{P}_{\text {SUTR-SON }}-\mathrm{P}_{\text {PIUN-SS }}\right) \times \mathrm{n}$

$\mathrm{E}_{\text {Konsv-SS }}=\mathrm{P}_{\text {Konsv-SS }} \times \mathrm{Oh}$

$\mathrm{J}_{\text {Konsv-SS }}=\mathrm{E}_{\text {Konsv-SS }} \times \mathrm{J}_{\mathrm{E}}$

where:

$\mathrm{J}_{\mathrm{Konsv}-\mathrm{SS}}$ : energy conservation is converted to $\mathrm{CO}_{2}$ emission $(\mathrm{Kg})$

$\mathrm{E}_{\text {Konsv-Ss }}:$ annual energy conservation (KWh/year)

$\mathrm{P}_{\text {Konsv-SS }}$ : conservation of electric power (KW)

$\mathrm{P}_{\text {PJUN-SON : }}$ the growth needs of electrical power for the lamp PJUN-SON.

$\mathrm{P}_{\text {PJUN-LED }}$ : power light PJUN-LED

$\mathrm{n} \quad$ : number of light 
Oh : operational hours

$\mathrm{J}_{\mathrm{E}} \quad: \mathrm{CO} 2$ emission factor $(\mathrm{Kg} / \mathrm{KWh})$

\section{Capasity of Solar Cell Module and Battery:-}

Capasity of solar cell module

1. $\mathrm{Fk}=$ multiflier factor due to losses and efficiency

2. $\mathrm{LPM}=$ duration of solar radiation

3. Energy generation $\left(\mathrm{W}_{\mathrm{SS}}\right)=$ Load $\mathrm{P}_{\mathrm{PJU}-\mathrm{LED}}$ (Watt) $\mathrm{x}$ Time (hour)

4. Solar cell module capacity $\left(\mathrm{P}_{\mathrm{SS}}\right)=($ Wss $\times \mathrm{Fk}) / \mathrm{LPM}$

\section{Battery capacity}

1. $\eta_{\text {Batt }}=$ battery efficiency and losses

2. Battery energy $\left(\mathrm{W}_{\text {Batt }}\right)=$ Load $\mathrm{P}_{\text {PJU-LED }} \mathrm{x}$ Charging time

3. Battery current required $\left(\mathrm{I}_{\text {BATT }}\right)=\left(\mathrm{W}_{\text {Batt }} / \mathrm{I}_{\text {Batt }}\right) / \eta_{\text {Batt }}$

\section{Result and Discussion:-}

Result:-

\section{The Electrical Needs of National Road Segment:-}

The electrical energy needs of the national road segment in 2019 is obtained by formulation, as follow :

Load of SON on length of primary arterial road The specified lighting quality of primery arterial road is 11-20 Lux. To obtain the lighting quality is used SON lamp, 400 Watt, with lamp height $11 \mathrm{~m}$, and distance between pole $40 \mathrm{~m}$. Then, the electrical energy consumption of primary arterial road along $1142 \mathrm{Km}$ with the operation time 4145 hours in 1 years, as follow:

the number of pole PJU is (the length of the $\mathrm{road} / 40$ ) +1

Electric power required on street lighting PJU

$\mathrm{P}_{\mathrm{PJU}-\mathrm{SUTR}}=400$ Watts $\mathrm{x}$ number of poles

$$
\begin{aligned}
& =400 \times 28551 \\
& =11.240 \times 10^{6} \mathrm{~W} \\
& =11.240 \mathrm{MW}
\end{aligned}
$$

Electrical energy needs of street lighting for the length of national primary arterial road segment is $\mathrm{W}_{\text {PJU-SUTR }}=400$ Watts $\mathrm{x}$ number of poles $\mathrm{x} 4145$ hours

$$
\begin{aligned}
& =400 \times 28551 \times 4145 \\
& =47.337 \times 10^{9} \mathrm{Wh} \\
& =47.337 \mathrm{GWh}
\end{aligned}
$$

\section{Load of SON on length of national primary colector road}

The specified lighting quality of primary collector road is 3-7 Lux. To obtain the lighting quality is used SON lamp, 180 Watt, with lamp height $8 \mathrm{~m}$, and distance between pole $40 \mathrm{~m}$. Then, the electrical energy consumption of primary collector road along $1490.22 \mathrm{Km}$ with the operation time 4145 hours in 1 years, as follow:

The number of pole PJU is (the length of the road/40) +1

Electric power required on street lighting PJU

$\mathrm{P}_{\mathrm{PJU}-\mathrm{SUTR}}=180$ Watt $\mathrm{x}$ number of pole

$$
\begin{aligned}
& =180 \times 37256 \\
& =6.706 \times 10^{6} \mathrm{~W} \\
& =6.706 \mathrm{MW}
\end{aligned}
$$

Electrical energy needs of street lighting for the length of national primary arterial road segment is $\mathrm{W}_{\text {PJU-SUTR }}=180$ Watts $\mathrm{x}$ number of poles $\mathrm{x} 4145$ hours

$$
=180 \times 37256 \times 4145
$$




$$
\begin{aligned}
& =27.796 \times 10^{9} \mathrm{Wh} \\
& =27.796 \mathrm{GWh}
\end{aligned}
$$

Then, Electrical energy needs of street lighting for total length of national road segment along $2632.22 \mathrm{Kms}$ is $75.133 \mathrm{GWh}$, and energy needs due to the increase of national road segment is $10.919 \mathrm{GWh}$

\section{Discussion:-}

Potential use of solar cells:-

To meet the energy needs of national public road lighting in North Sumatera province can be analized from the value of electrical energy generated by each solar cell module and overall need of solar cell panels required to replace the energy generated by conventional power generation.

By using solar cell modules, the need for electrical energy for public road lighting on national roads in 2019 and its increase can be obtained as follows:

\section{Load of LED light on total length of national road}

The specified lighting quality is 11-20 Lux. To obtain the lighting quality is used LED lamp, 100 Watt, with lamp height $7 \mathrm{~m}$, and distance between pole $40 \mathrm{~m}$. Then, the electrical energy consumption of primary arterial road and primary collector road along $2632,22 \mathrm{Km}$ with the operation time 4145 hours in 1 years, as follow:

the number of pole PJU is (the length of the road/40) +1

Electric power required on street lighting PJU

$\mathrm{P}_{\mathrm{PJU}-\mathrm{LED}}=100 \mathrm{Watt} \mathrm{x}$ number of poles

$=100$ Watt $\times 65807$

$=6.580 \mathrm{MW}$

Electrical energy needs of street lighting for total length of national road segment is

$\mathrm{W}_{\text {PJU-LED }}=100$ Watt $\mathrm{x}$ number of poles $\mathrm{x} 4145$ hours

$=100$ Watt $\mathrm{x} 65807$ poles $\mathrm{x} 4145$ hours

$=27.277 \mathrm{GWh}$

Load of LED light due to the increase of national road segment

On the increase of national roads along $382,56 \mathrm{Kms}$, the light load of LED lamp required is equal to

$\mathrm{W}_{\mathrm{PJU}-\mathrm{LED}}=3.964 \mathrm{GWh}$

Capacity of solar cell module and battery

Capacity of solar cell

Sunlight can generate electrical energy at peak times of $1000 \mathrm{Watts} / \mathrm{m}^{2}$ (Pierre et all, 2013). On the efficiency of solar panels by $15 \%$ with the size of each panel with area of $1 \mathrm{~m}^{2}$, solar cell can produce an output power of 150 Wp.

Solar cell module capacity to serve the load of national street lighting PJU-LED, 100 Watts for 12 hours, at 18.006.00 , with 1.2 as multiplier factor and 5.7 hours is the duration of solar exposure. Then,

Load $\mathrm{P}_{\text {PJU-LED }}=100$ Watts

The energy requirement to serve the load

$\mathrm{P}_{\text {PJU-LED }}=100$ Watt is

Energy generation $\left(\mathrm{W}_{\mathrm{SS})}=100\right.$ Watts $\mathrm{x} 12$ hours

$=1200 \mathrm{Wh}$

$=1.2 \mathrm{KWh}$

Solar cell modul capacity $\left(\mathrm{P}_{\mathrm{SS}}\right)=(100$ Watts x 12 hours x 1.2$) / 5.7$ hours

$$
=252 \mathrm{Wp}
$$

The need for solar cell modules to meet PJU-LED, 100 Watts is 2 set of solar cell modules each with a capacity of $130 \mathrm{Wp}$. 


\section{Capacity of battery:-}

1. Load $\mathrm{P}_{\mathrm{PJU}-\mathrm{LED}}=100 \mathrm{Watts}$

2. Battery voltage used $=12$ Volts

3. Battery charging time $=12$ hours

4. Eficiency tubular battery $\left(\eta_{\text {Batt }}\right.$ ) dan losses $=80 \%$

5. Battery energy $\left(\mathrm{W}_{\text {Batt }}\right)=\mathrm{P}_{\mathrm{PJU}-\mathrm{LED}} \times \mathrm{B}$ Battery charging time

$$
\begin{aligned}
& =100 \times 12 \\
& =1200 \mathrm{Wh}
\end{aligned}
$$

6. The required Battery current $\left(\mathrm{I}_{\mathrm{BATT}}\right)=\left(\mathrm{W}_{\text {Batt }} / \mathrm{I}_{\text {Batt }}\right) / \eta_{\text {Batt }}$

$$
=(1200 / 12) / 0.8
$$

$=100 / 0.8$

$=125 \mathrm{Ah}$

\section{$\mathrm{CO}_{2}$ Emission Reduction:-}

Energy concervation obtain by replacing the conventional energy comsumption into solar energy source is as

\begin{tabular}{|c|c|c|c|}
\hline \multirow{2}{*}{$\begin{array}{l}\text { Emission } \\
\text { factor }\end{array}$} & \multicolumn{2}{|l|}{ All National Road } & Growth of National Roads \\
\hline & $\begin{array}{ll}\text { Energy } & \text { Conservation } \\
\text { Reduction } & (\text { GWh })\end{array}$ & $\begin{array}{cc}\mathrm{CO}_{2} & \text { Emission } \\
(\mathrm{kT} \text { Ton } & \mathrm{CO} 2)\end{array}$ & $\begin{array}{llll}\begin{array}{l}\text { Energy Conservation } \\
\text { Reduction }\end{array} & \mathrm{CO}_{2} & \text { Emission } \\
(\mathrm{GWh}) & (\mathrm{kTon} & \mathrm{CO} 2)\end{array}$ \\
\hline 1.14 & 47.856 & 54.555 & 7.928 \\
\hline
\end{tabular}
follows,

Table 1:- $\mathrm{CO}_{2}$ Emission Reduction

\section{Conclusion:-}

Energy conservation is the act of maintaining energy by reducing energy comsumption or replacing energy sources to obtain the same benefits. In thi study, energy conservation obtain by replacing conventional energy sources with solar cells for the total length of national street lighting is $47.856 \mathrm{GWh}$ in a year, and reduced carbon emission by $54.555 \mathrm{kTon} \mathrm{CO}_{2}$.

On the length of the national road increase, energy conservation is obtained at $6.955 \mathrm{GWh}$ in a year, and reduce carbon emission by $7.928 \mathrm{kTon} \mathrm{CO}_{2}$.

In General, The reduction in carbon emissions will provide the cleaner air conditions.[8], and for street light, carbon emission canbe reduced by using light bulbs with high lamp efficacy[9].

\section{Acknowledgement:-}

Thank you for the support given by the University of Darma Agung, both spirit and material for the completion of this research.

\section{References:-}

1. Dhingra, T. Singh, Energy Efficient Lighting - a way to Conserve Energy, International Journal of Energy ,Vol.3 Issu 1,2009

2. A. Mohamed, T.K. Mohamed, A Review Of Elektrical management Techniques Supply and Consumer Side (Industries), Journal Of Energy Southern Africa Vol.20, No.3, August 2009.

3. Biswas, S. Mukherjee, A. Ghosh, Conservation of Energi : a Case Study on Energi Conservation in Campus Lighting in an Institution, International Journal of Modern Engineering Research(IJMR), Vol.3, Issu 4, ISSN : 2249-6645, 2013.

4. H.Elaydi, I. Ibrik, E. Koudary, Conservation and Management of Electrical Energy in Gaza Strip Using Low Cost Investment, International Journal of Engineering Reseach and Aplication (IJERA) ISSN: 2248-9622, Vol.2, Issu 4, pp.1152-1157, 2012

5. V.Padmini, Conservation of Electrical Energi on SET-JU Campus through Auditing and Optimal Alternative Techniques, International Journal of Renewable Energi and Environmental Engineering, Vol.02, N0.2, ISSN: 2348-0157, 2014. 
6. D.Marcova, S.Platikanov, M. Konstantinoff, P.Tsanov, Opportunities for usingrenewable energy sources in Bulgaria, Contemporary materials (Renewable energy sources), II-2, UDK 620.91/.92:551.55(497.2) doi:10.5767/anurs. cmat.110202.en.178M, 2011.

7. https://gautamakarisma.files.wordpores.com/2013/solar-irradiance.jpg

8. K.Fredrich, L.Yunju, S.Yufang, T.Timn, W.Andreas, Greenhouse gas emissions from nitrogen fertilizer use in China, Environmental science \& Policy. Vol.13, Issue 8, Dec. 2010, ISSN 1462-9011, 2010.

9. J.Napitupulu, H.Mawengkang, U.Ba'afai, Nasruddin M.N, Model of Sustainable Electrical Power management : Lamp Efficacy of the National Street Lighting in North Sumatera Province, Proceeding of MICoMs, 2017, 609-619, 4 May 2018, ISSN : 2516-2853. 